\title{
The megazoobenthos of the Scotia Arc islands*
}

\author{
ANA RAMOS \\ Instituto Español de Oceanografía, Puerto Pesquero s/n, E-29640 Fuengirola, Málaga, Spain.
}

\begin{abstract}
SUMMARY: Megabenthic epifauna composition and distribution from the Scotia Arc islands based on data collected during the Antarctic summer of 1986-87 is presented. Samples were taken from bottom trawl catches at 345 stations (29 at Shag Rocks, 104 at South Georgia, 8 at the South Sandwich Islands, 93 at the South Orkney Islands, 46 at Elephant Island, and 65 at the South Shetland Islands), from 26 to $643 \mathrm{~m}$ depth. Among the most striking features of the faunistic composition of the area, pointed out by multivariate analysis, are the singularity of Shag Rocks, closer to the Magellan region, and of the volcanic South Sandwich Islands, as well as the similarity of South Georgia and the South Orkney Islands and that of the islands nearest to the Antarctic continent, especially Elephant Island and the South Shetlands Islands. This similarity is due to the higher frequency and abundance of the most characteristic taxa in the Antarctic epibenthos, such as sessile suspension feeders (sponges, calcareous bryozoans, pennatulids, crinoids), and motile fauna with a wide variety of trophic strategies (asteroids, holothurians, pycnogonids, large isopods and gammarids). These data confirm the fact that the long-lived suspension-feeder communities, demosponges and hexactinellids, characteristic of the Antarctic epibenthos stretch to the eastern shelf of South Georgia without reaching the north-west of this island, the South Sandwich Islands, and Shag Rocks. Some of the zones with rich communities of sessile filter-feeders, long-lived sponges or reef formations of calcareous bryozoans or serpulids should be proposed as Specially Protected Areas.
\end{abstract}

Key words: Megabenthos, composition, distribution, Scotia Arc Islands.

RESUMEN: El MEGAZOOBENTOS EN LAS ISLAS DEL ARCO DE EsCocia. - En el presente trabajo se ofrece una visión de conjunto sobre la composición y distribución de la epifauna megabentónica en las islas del Arco de Escocia. Los datos proceden de las capturas de la campaña española 'Antártida 8611', que en 1986-87 realizó 345 arrastres de fondo en la zona (29 en Shag Rocks, 104 en Georgia, 8 en Sandwich, 93 en Orcadas, 46 en Elefante y 65 en Shetlands) a profundidades comprendidas entre 26 y $643 \mathrm{~m}$. Entre los hechos mas interesantes que ponen de manifiesto los análisis multivariantes se encuentran la particularidad de Shag Rocks, el área más próxima a la región de Magallanes, y de las volcánicas islas Sandwich, así como la similaridad de Georgia del Sur y Orcadas y de las islas cercanas al continente antártico, en especial Elefante y Shetlands. Esta similaridad viene determinada por la mayor frecuencia y abundancia de los taxones más característicos del epibentos antártico, tanto suspensívoros sésiles (esponjas, briozoos calcáreos, pennatúlidos, crinoideos), como móviles y con variedad de estrategias tróficas (asteroideos, holoturoideos, picnogónidos, grandes isópodos y gammáridos). La información permite constatar la extensión de las comunidades de suspensívoros de larga vida, demosponjas y hexactinéllidas, características del epibentos antártico, hasta la plataforma este de Georgia, sin que alcancen el noroeste de esta isla, las islas Sandwich, ni los islotes Shag. Algunas de las zonas con ricas comunidades de filtradores sésiles, esponjas de larga vida o formaciones arrecifales de briozoos calcáreos o serpúlidos, podrían ser propuestas para su designación como Áreas Especialmente Protegidas.

Palabras clave: Megabentos, composición, distribución, islas del Arco de Escocia

\section{INTRODUCTION}

The Scotia Arc, a series of trenches and elevations spreading over more than $1,500 \mathrm{~km}$ between the south-

\footnotetext{
*Accepted October 1, 1999.
}

ern tip of South America and the Antarctic Peninsula (Acosta et al., 1989) constitutes a particularly important area for understanding the history of the Southern Ocean marine fauna (Clarke and Crame, 1989).

It is difficult to establish a detailed geological history of the Scotia Arc (Clarke and Crame, 1989). 
However, it is known that until the mid-Cretaceous, the South Georgia shelf remained directly linked to South America (Dalziel, 1983; Headland, 1984) and the South Orkneys were then still attached to the Antarctic Peninsula (Dalziel, 1983). The volcanic South Sandwich Islands developed much later, only 4 Ma ago (Acosta et al., 1989).

It is now generally accepted that most of the Antarctic benthic fauna is very old, originating from propagules that moved with the continents (Picken, 1985; Dayton, 1990). According to one theory, the Scotia Arc would constitute a pathway for species exchange between the Subantarctic and Antarctic regions (Picken, 1985), which would have kept the benthic Antarctic ecosystem from total isolation. However, this hypothesis remains unproven (Dayton, 1990) and the current oceanographic situation, with the Convergence barrier and the limited dispersal ability of many forms, makes it likely that exchange is very slow (Clarke and Crame, 1989).

Many expeditions have collected material from the South Georgia, South Sandwich, South Orkney and South Shetland islands (reviews in Dell, 1972; Dayton, 1990), and some faunistic groups, such as amphipods and polychaetes, have been object of detailed zoogeographical analysis (Knox and Lowry, 1977). Most benthic studies, however, have mainly been systematic (Arntz et al., 1994).

Although some information is available regarding the distribution of different epibenthic taxa in Antarctic waters, including the Scotia Arc (Dell, 1972), it is still unknown if the faunistic structure of the benthos of these islands is similar to that found in the Antarctic and Magellan areas (Arntz and Gorny, 1996). Particularly, it is unknown if their shelves also house the rich three-dimensional communities of sessile suspension feeders that are characteristic of the high Antarctic benthos and are found around the continent (Dayton, 1990; Dayton et al., 1994).

In spite of the interest of the region, information on the Scotia Arc benthos is extremely limited and almost nothing is currently known about its composition and distribution (Arnaud, 1992). A survey of the literature shows only Platt's work on King Edward's Cove (1979), South Georgia Island. Studies on the South Orkneys and South Shetlands are somewhat more numerous, mostly focusing on Signy Island (Hardy, 1972; Barnes, 1995a, b) and some of the South Shetlands shallow bays (Gallar- do, 1992), especifically those of Greenwich (Gallardo and Castillo, 1969; Gallardo et al., 1977) and Deception islands (Retamal et al., 1982). During the last decade, this information has been expanded by the work of Jazdzewski et al. (1986), Sáiz-Salinas et al. (1997) and Arnaud et al. (1998) in the South Shetland area, as well as that of Mühlenhardt-Siegel $(1988,1989)$ in the South Orkneys, South Shetlands, Elephant Island, and the Antarctic Peninsula. Since the methodology used in all those projects was aimed at studying the infauna, they offer little information on the characteristic components of the megabenthos, particularly regarding the distribution of the rich three-dimensional communities of suspension feeders that are so characteristic of the Antarctic epifauna (Arntz, 1997; Arntz and Gorny, 1996).

During the $R / V$ Polarstern campaign in 1989, various hauls were taken at Elephant Island, using trawling methods specifically designed for epibenthos sampling (Galéron et al., 1992). In Spanish campaigns on board the $R / V$ Hespérides, using both Agassiz and rock-dredge trawls, sampling was conducted in the South Shetland Island zone, in the Bransfield Strait and the Drake Passage (Arnaud et al., 1998; Ramil and Ramos, 1997). Likewise, during the Spanish campaign for fishery prospecting 'Antártida 9101' (Balguerías, 1991), information on the megabenthos was collected from 124 hauls on the South Orkney shelf (Ramos and Sobrino, 1991).

During the Antarctic summer of 1986-87, Spain carried out a trawling campaign in the Scotia Arc region, called 'Antártida 8611' (Balguerías, 1989), which, due to the notable scarcity of benthic data in this area (Arnaud, 1992), offered a unique opportunity for expanding knowledge of the Antarctic benthos. In addition to the significant taxonomic and zoogeographical interest of the collected material, most of which has already been analyzed and published (see: Casas, 1994; Conde and Gallardo, 1991; García et al., 1994; López de la Cuadra and GarcíaGómez, 1997; Munilla, 1991; Peña-Cantero and García-Carrascosa, 1996), the data obtained at 345 trawling stations (Ramos, 1987; Ramos et al., 1987), despite some methodological difficulties discussed in Elephteriou and Holme (1984), made it possible to obtain the first overall view of the composition and distribution of epibenthic megafauna off the Scotia Arc islands, and to compare them with other Antarctic and the Magellan regions (Arntz and Gorny, 1996). 


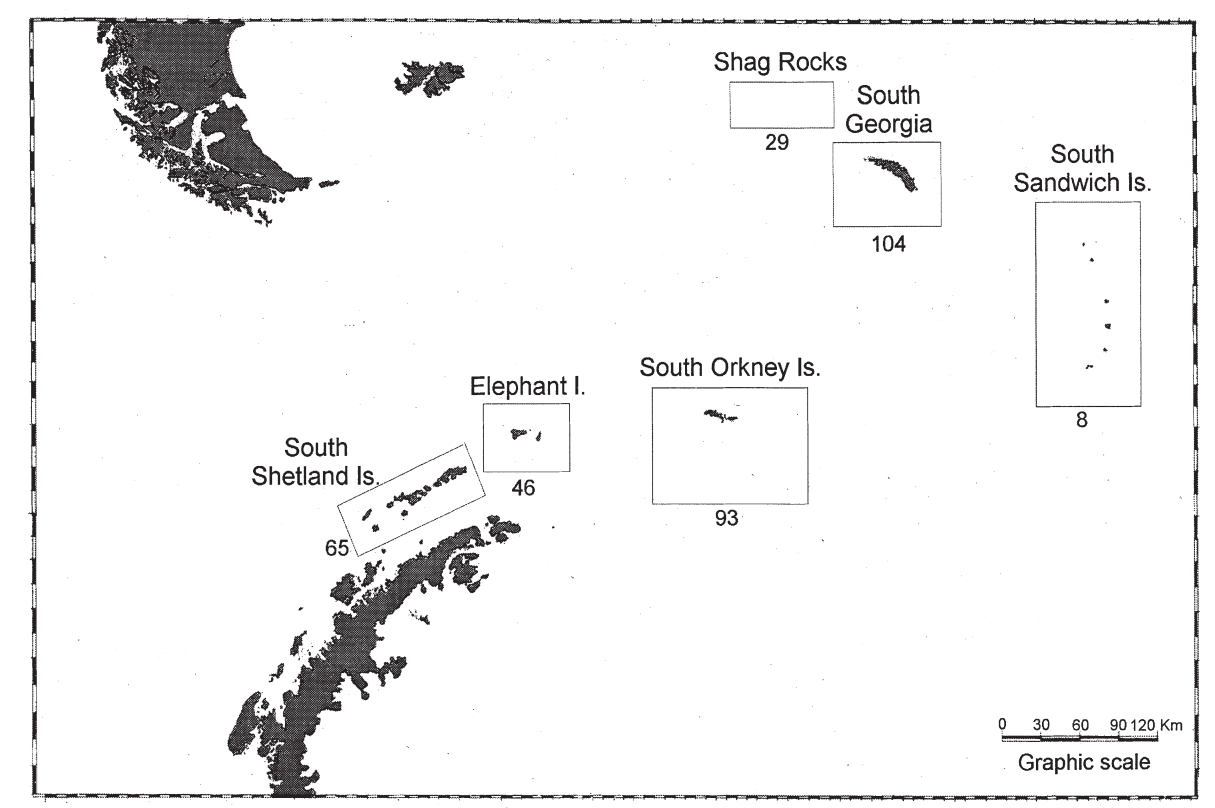

FIG. 1. - Study area, with station numbers by archipelago: Shag Rocks (29), South Georgia Island (104), South Sandwich Islands (8), South Orkneys (93), Elephant Island (46) and South Shetlands (65).

\section{MATERIAL AND METHODS}

\section{Field sampling}

The Spanish campaign 'Antártida 8611' was carried out from November 1986 to February 1987 on the continental shelf of the Scotia Sea islands, with a commercial fishing vessel specially equipped for this research. A total of 345 hauls were obtained from 26 to 643 m depth (29 at Shag Rocks, 104 at South Georgia, 8 at the South Sandwich Islands, 93 at the South Orkney Islands, 46 at Elephant Island and 65 at the South Shetland Islands) (Fig. 1) with a commercial trawl, using the swept-area method and following a stratified random sampling procedure. Each archipelago was considered an independent region and divided into depth strata (Balguerías, 1989).

The bottom trawl used for sampling had 12 and $3.5 \mathrm{~m}$ of horizontal and vertical openings, and 68 and $40 \mathrm{~mm}$ mesh on the inner and covered codends, respectively. It was equipped with three sections of bobbins ( $56 \mathrm{~cm}$ diameter) on the footrope, so that it could be used on all kinds of seabed. Hauls were 30 minutes long, at a vessel speed of 3 knots and the location was determined with a GPS satellite navigation system (Balguerías, 1989).

Data on numerical abundances of individuals for each megabenthic taxon identifiable de visu, based on an empirical progressive scale of five abundance degrees, for each haul, have been used in this work
(Ramos, 1987). In addition, oceanographic data and information on sediment and plankton were collected (Álvarez de Meneses, 1989; Acosta et al., 1989; Jansá, 1989; Mariño, 1989).

No trawling was possible off the southern South Shetlands, because the shelf is practically non-existent there. Only eight hauls could be carried out off the South Sandwich Islands due to their rugged, volcanic sea-bottom (Balguerías, 1989).

\section{Data analysis}

Data have been processed and analyzed independently for each island group: Shag Rocks, South Georgia, South Sandwich Islands, South Orkney Islands, Elephant Island and South Shetland Islands (Fig. 1). The relative frequency of 27 highest-ranking taxa was calculated as the percentage of stations at which they were found in any abundance, as well as the abundance of these taxa, expressed as the percentage of stations at which they were found in abundant or massive quantities (4 and 5 degrees in the empirical scale of abundance).

Data of frequency and semi-quantitative abundance of the 27 taxa by island group have been transformed in a similarity matrix by means of the BrayCurtis coefficient and then used for analysis of hierarchical clustering (complete linkage) and ordination by Multi-Dimensional Scaling (MDS), as well as for testing the similarity and dissimilarity average in and among island groups (Clarke and Warwick, 1994). 
RESULTS

\section{General description of faunal composition and distribution}

\section{Shag Rocks}

Ophiuroids, echinoids and hydroids appeared in more than $60 \%$ of the hauls, followed by asteroids, corals, sponges, actinians and gorgonians (Fig. 2). Echinoderms were the dominant taxon, due to the abundance in $80 \%$ of the stations, mainly in the southern zone, of two large ophiuroid species, Astrostoma agassizii Lyman, 1875 and Asprospartum gigas. The latter was collected exclusively around these islands. Suspension feeders were represented by colonial cnidarians (hydroids, gorgonians, alcyonarians), dominant in two very restricted western areas. Ascidians, mainly solitary, small species, were dominant in the south-east. The remaining taxa were not very representative and included small sponges. As shown in Figure 2, the only outstanding groups were decapods of the Lithodidae family (stone crabs), belonging to the genus Paralomis, and some polychaetes (Aphroditidae). Brachiopods, cirripedes, pennatulids, large gammarids and crinoids were not collected; holothurians were rare, and asteroids were almost exclusively represented by the species Labidiaster annulatus (Sladen, 1889).

\section{South Georgia Island}

As off Shag Rocks, ophiuroids were the most frequent taxon, being found in $70 \%$ of the hauls (Fig. 3 ), with a clear dominance in the central part of the

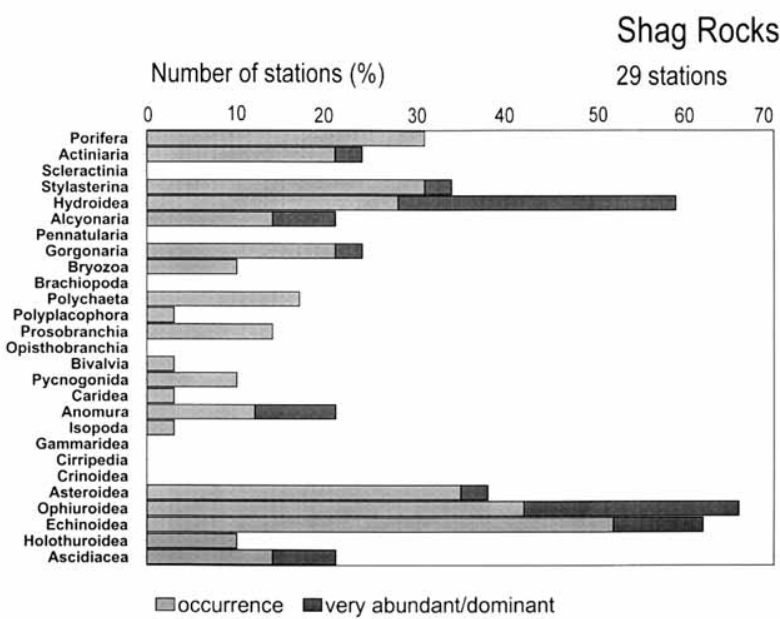

FIG. 2. - Shag Rocks. Percentage of stations where major megabenthic taxa occurred or were very abundant/dominant.

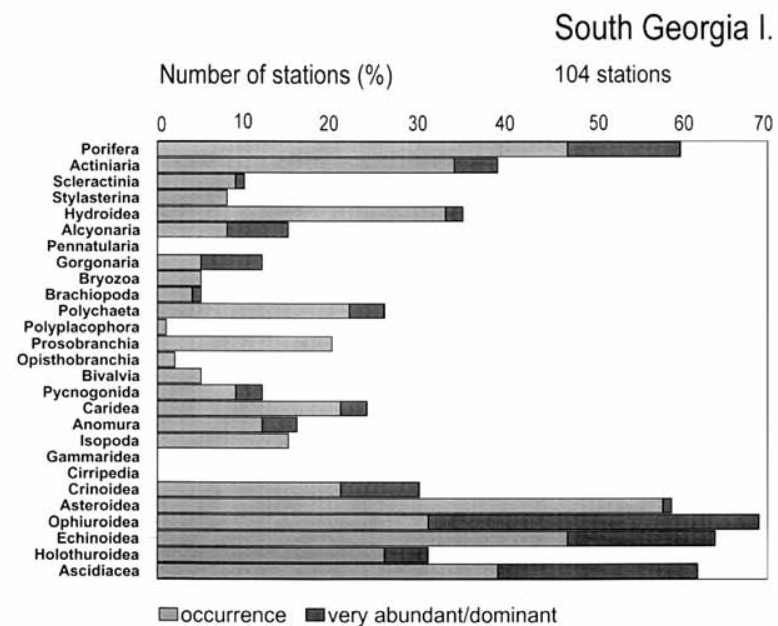

FIG. 3. - South Georgia Island. Percentage of stations where major megabenthic taxa occurred or were very abundant/dominant.

southern shelf, due in particular to the species $A$. agassizii. Ophiuroids were followed by echinoids and ascidians, sponges and asteroids, with an occurrence rate of $60-65 \%$, but with very different abundances, as clearly reflected in Figure 3. Ascidians were represented by solitary as well as colonial forms, with a clear dominance of Distaplia cylindrica (Lesson, 1830) at one-fourth of the stations. Although found in lower proportions than at Shag Rocks, colonial cnidarians were represented by the same taxa, with actinians being found at $40 \%$ of the stations. Lithodidae were found almost as frequently as at Shag Rocks, while other groups missing at Shag Rocks -including crinoids, caridean decapods and brachiopods- appeared off these islands.

Higher abundances were located to the west, and more generally, to the east of Clerke Rocks. Large hexactinellids and demosponges were dominant almost exclusively on the north-eastern shelf at 150$200 \mathrm{~m}$. The poorest zone seemed to be the northwest of the island. At the easternmost station a massive formation of serpulids was found (Ramos and San Martin, 1999).

\section{South Sandwich Islands}

Data from the South Sandwich Islands are not very representative because they are based on a very small number of hauls, as mentioned in Material and Methods. However, in all of the stations ascidians -represented by one or two large Molgulidae species- were clearly dominant (Fig. 4). These were followed by echinoderms (ophiuroids and asteroids), which were also present in all the stations, but in lower abundances. Opisthobranchs and pennatulids were also abundant. 


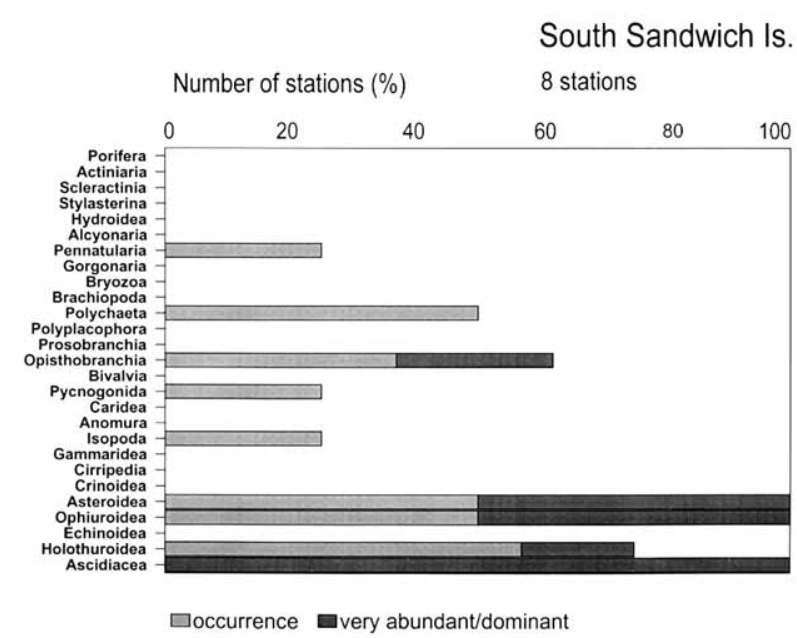

FIG. 4. - South Sandwich Islands. Percentage of stations where major megabenthic taxa occurred or were very abundant/dominant.

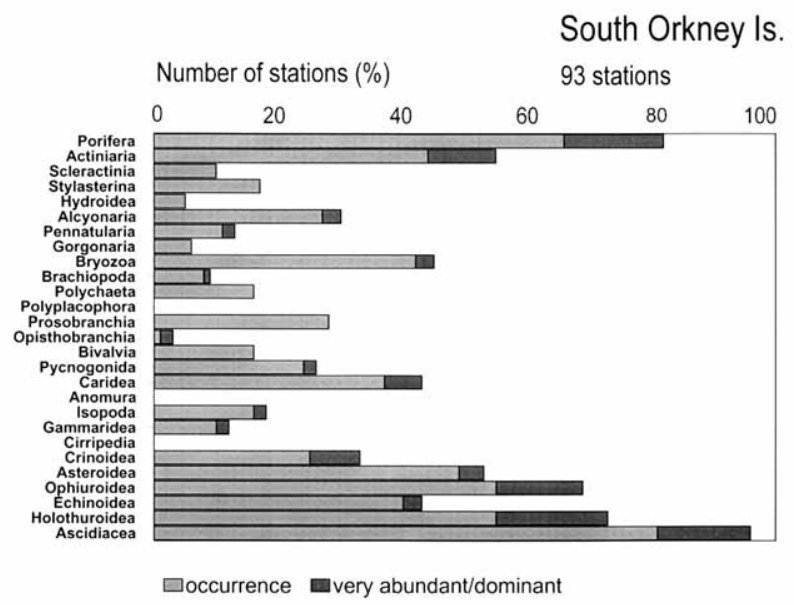

FIG. 5. - South Orkney Islands. Percentage of stations where major megabenthic taxa occurred or were very abundant/dominant.

\section{South Orkney Islands}

The fauna from the South Orkney Islands was composed of suspension feeders (ascidians and sponges) which were the most frequent taxa, appearing in $80 \%$ and $70 \%$ of hauls, respectively (Fig. 5). Although echinoderm occurrence was generally similar to that of other areas, the balance favoured holothurians, dendrochirotids as well as aspidochirotids, which, like ophiuroids, were found in $60 \%$ of the stations. These four groups were also abundant or dominant in almost $20 \%$ of the hauls. There was a striking frequency in the South Orkneys of some taxa very characteristic of the Antarctic benthos, which were practically absent in the hauls from the more northerly islands. Bryozoans appeared at more than $40 \%$ of the stations and crinoids and pycnogo- nids at $20 \%$. Large isopods, pennatulids and brachiopods were also more frequent (Fig. 5).

These islands showed a marked difference in the megabenthos distribution between northern and southern parts. The wide, muddy southern and western shelves were poor, comprising only large aspidochirotid holothurians, small ascidians and some arthropods, with the exception of an area in the east at 400-500 m depth where pennatulids were abundant. Conversely, the northern area had high abundances, similar to those found at South Georgia, due to the presence of three-dimensional communities from 100 to $300 \mathrm{~m}$ depth. The large sponges were located at the east and north-east of Laurie Island and south of Signy Island. Calcarean bryozoans occupied a perfectly delimited zone north of Powell Island, where we assume they must constitute a reeftype formation that provides a stable and protected habitat for many juveniles and small species of asteroids, ophiuroids and dendrochirotid holothurians. In this area, massive communities of ascidians were also found.

\section{Elephant Island}

Although off Elephant Island asteroids were the most frequent and abundant epibenthic group, with an occurrence rate of $80 \%$, a wide range of taxa appeared frequently at $35-55 \%$ of the stations. They were, in decreasing order: sponges, echinoids, ascidians, bryozoans, holothurians, ophiuroids, pycnogonids and crinoids (Fig. 6). In terms of abundance, the sponges were the most representative group followed by echinoderms, with asteroids being the most noteworthy group. There was a striking

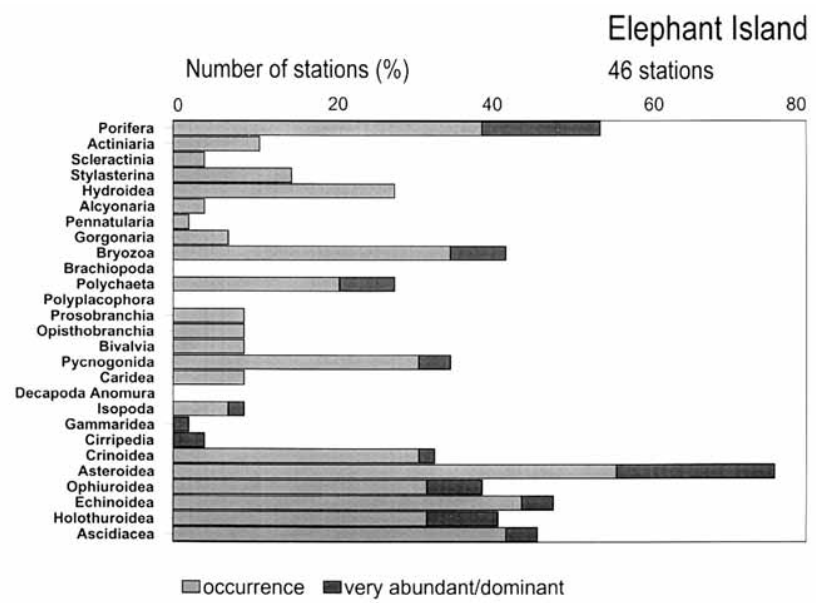

FIG. 6. - Elephant Island. Percentage of stations where major megabenthic taxa occurred or were very abundant/dominant. 
absence of A. agassizii, the species responsible for the high ophiuroid abundance in other areas, the group being represented here by small species.

The Elephant Island shelf, muddy on the western side, also proved to be poor in megabenthic fauna. The greatest abundances were recorded both south of Gibbs Island and in some western zones, due to large sponge communities at depths greater than 250 $\mathrm{m}$. There was a belt of colonial calcareous bryozoans south of Elephant Island, the largest island here, and there were ascidians both to the north and east of that island, at depths above $250 \mathrm{~m}$.

\section{South Shetland Islands}

In the South Shetland Islands asteroids were by far the most frequent taxon, appearing in identical occurrence $(80 \%)$ and abundance $(20 \%)$ rates, followed, as in Elephant Island, by ophiuroids and holothurians which were collected at $40 \%$ of the stations (Fig. 7). Among the filter-feeder taxa, the highest percentage of abundance corresponded to Porifera, particularly to large hexactinellids; groups such as ascidians and bryozoans were somewhat less frequent. A series of taxa characteristic of Antarctic megabenthos were found here with a much higher frequency. This was the case of pycnogonids, which were collected at $40 \%$ of the stations, crinoids, errant polychaetes, large isopods and gammarids (Fig. 7).

In the South Shetland Islands, the epifauna seemed to be concentrated to the north-east of King George Island. Large sponges, particularly hexactinellids were located in this zone, always deeper than $150 \mathrm{~m}$. In the same area, a reef structure of cal-

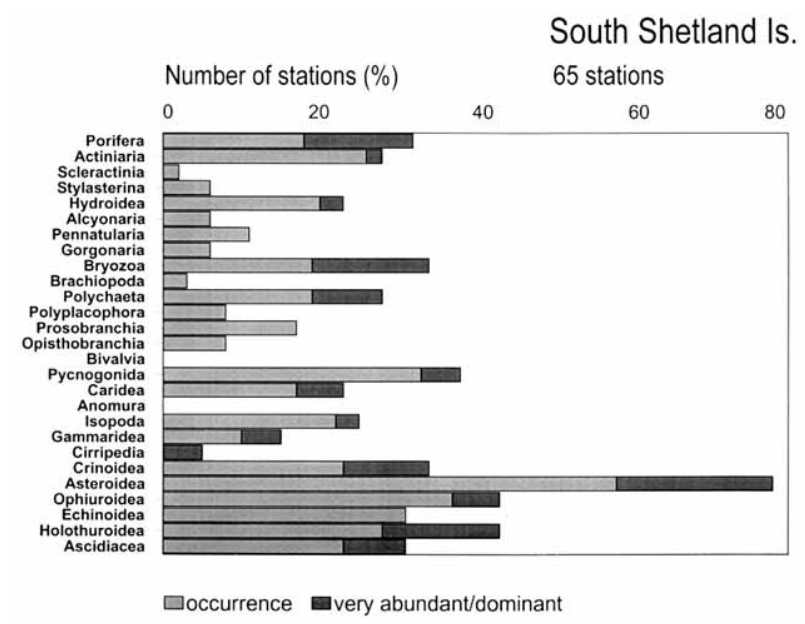

FIG. 7. - South Shetland Islands. Percentage of stations where major megabenthic taxa occurred or were very abundant/dominant.

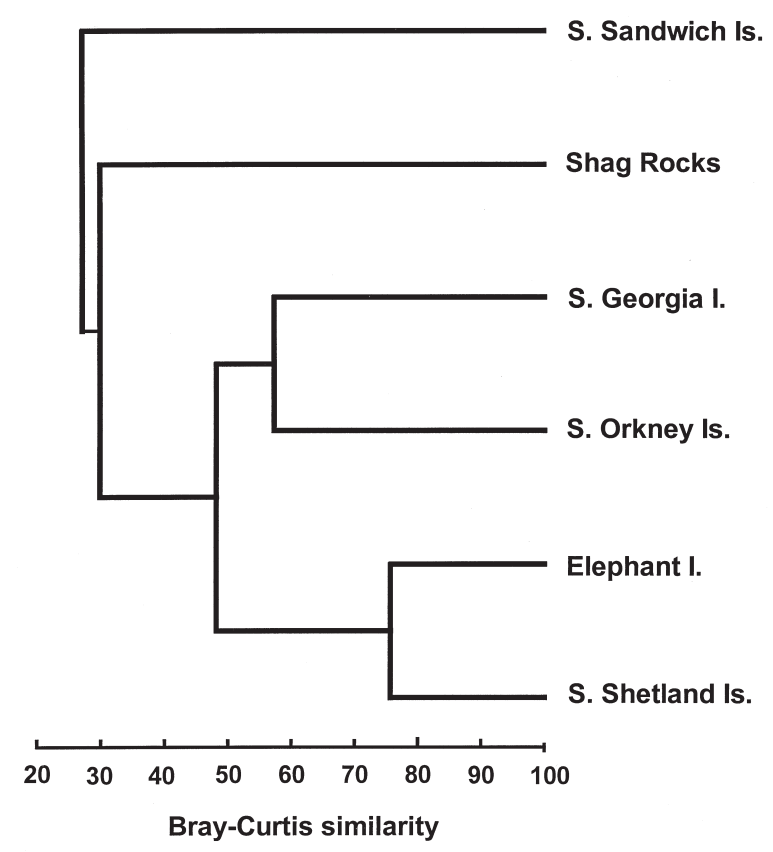

FIG. 8. - Dendrogram of the island groups using complete linkage clustering from Bray-Curtis similarity on 27 faunistic taxa frequency and semi-quantitative abundance.

careous bryozoans, similar to that off the South Orkney Islands and Elephant Island, but more widely extended, stretched from the north-western tip to the central part of King George. With the exception of this area, the megabenthic epifauna seemed to be scarcer than around Elephant Island.

\section{Faunistic similarity among islands}

As shown by the dendrogram resulting from hierarchical clustering, a clear similarity between the benthic megafauna of Elephant Island and the

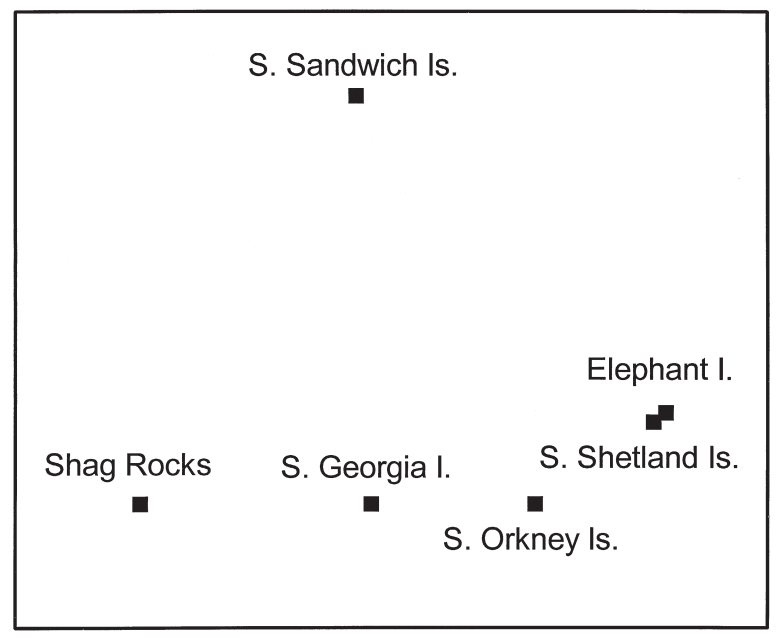

FIG. 9. - Two-dimensional ordination (MDS) of the island groups. 
TABLE 1. - Dissimilarity percentage among island groups

\begin{tabular}{|c|c|c|c|c|c|}
\hline & Georgia & Sandwich & Orkneys & Elephant & Shetlands \\
\hline Shag Rocks & 51.86 & 75.92 & 61.95 & 66.91 & 67.38 \\
\hline Georgia & - & 63.32 & 49.70 & 57.00 & 55.21 \\
\hline Sandwich & - & - & 66.36 & 67.12 & 66.18 \\
\hline Orkneys & - & - & - & 48.31 & 47.33 \\
\hline Elephant & - & - & - & - & 44.77 \\
\hline
\end{tabular}

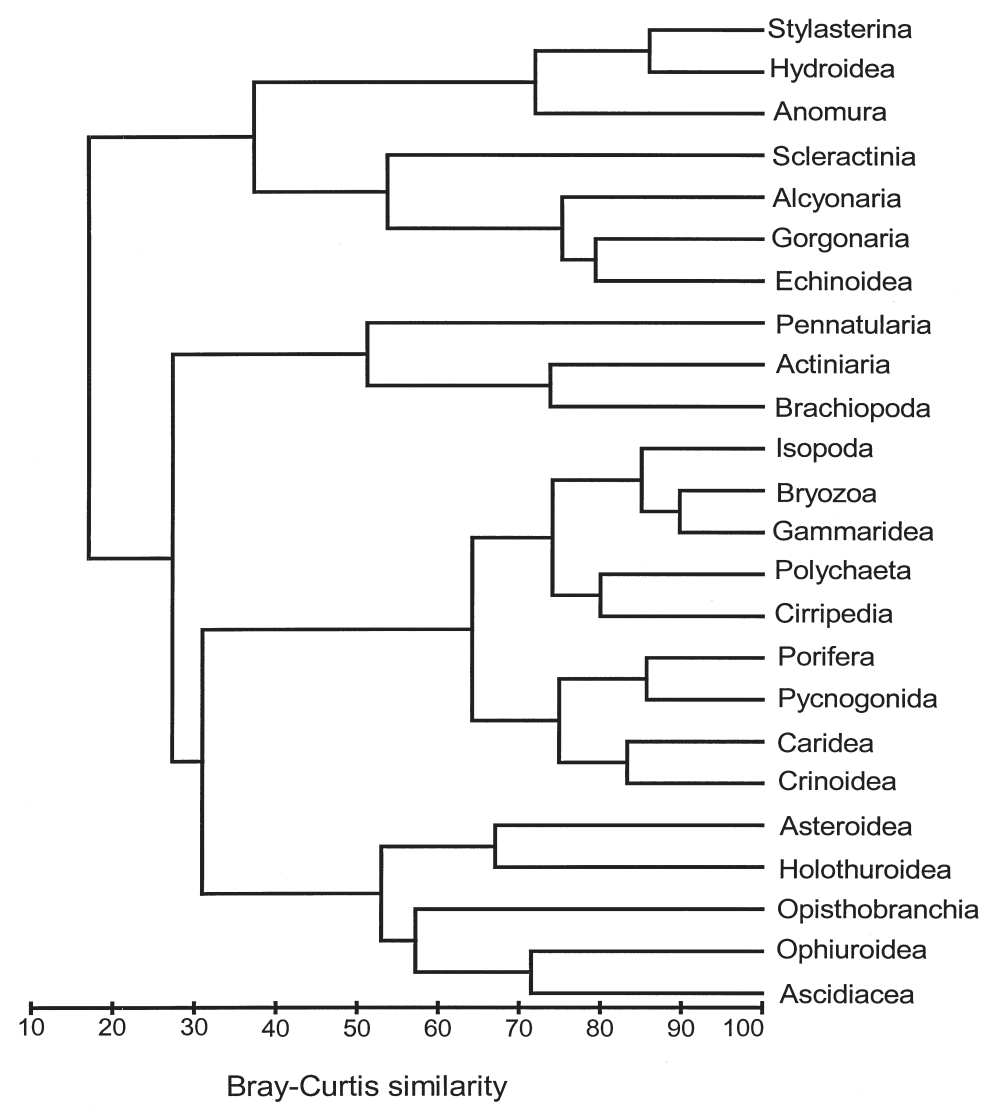

FIG. 10. - Dendrogram of the 27 faunistic taxa using complete linkage clustering from Bray-Curtis similarity on taxa frequency and semiquantitative abundance at the six island groups.

South Shetland Islands seems to exist. At least in relation with the frequency and general abundance of the larger taxa, the clustering analysis placed these two close island groups at an almost $80 \%$ similarity level (Fig. 8). Curiously, despite their actual geographical distance, also South Georgia and the South Orkney Islands are grouped at a similarity level of $60 \%$. The Shag Rocks and, mainly, the South Sandwich Islands seem singular island groups with a very low faunistic similarity with the rest. The grouping obtained through the ordination of multidimensional scaling (MDS) (Fig. 9) is identical to the dendrogram, confirming the faunistic proximity of Elephant and South Shetlands, and the distance of the South Sandwich islands.
The values of average dissimilarity (Table 1) also show minor differences between South Georgia and South Orkneys (49.70\%), between the latter and Elephant Island $(48.31 \%)$ and South Shetlands $(47.33 \%)$ and, particularly, between the last two island groups $(44.77 \%)$. The high dissimilarity of Shag Rocks with the rest, $62-76 \%$ (52\% with South Georgia), was mainly due to hydrozoans, ophiuroids and echinoids, whereas that of the South Sandwich Islands (63-76\%) was marked by the ascidians. The clustering analysis among faunistic taxa clearly separates, at an $80 \%$ of similarity level, the more characteristic components of the Antarctic megabenthos (Porifera, Bryozoa, Isopoda, Gammaridea, Crinoidea, etc), from the taxa with higher frequency and 
abundance in northern islands (Cnidaria, Echinoidea and Decapoda Anomura), at South Georgia and Shag Rocks islands (Fig. 10).

\section{DISCUSSION}

\section{Methodology}

Although the use of the trawling method for epibenthos studies has been widely disputed, due to the fact that no catchability coefficient for the fauna is available, it can be used as a semi-quantitative method with comparative objectives (Elephteriou and Holme, 1984). Even with the problems of the methodology employed in the present study, the publication of data collected during the 'Antártida 8611' campaign is justified due to the high number of trawling stations and the sampling strategy used (Balguerías, 1989). It provides a first overall, largescale view of the general distribution pattern of the epibenthos in the Scotia Sea, expanding the scarce available information about this region.

As soon as the oceanographic, planktonic and sedimentological data also collected during the survey are available (Álvarez de Meneses, 1989; Mariño, 1989; Jansá, 1989; Acosta et al., 1989), they should enable us to propose some hypotheses that could explain the abundance or scarcity in those remote islands of suspension feeders or groups with a wider-ranging trophic spectrum, which represent two very different types of Antarctic benthic communities (Arnaud, 1992).

\section{Faunistic analysis}

The studies conducted to date seem to indicate that the faunistic structure of the Magellan and Antarctic areas, at least as far as the megabenthos is concerned, are very different, even though both regions remained more closely connected until only 20 million years ago (Arntz, 1997).

In the high Antarctic, where the infauna seems rather inconspicuous, many epifaunal communities are characterized by their richness (Beliaev, 1958; Arntz, 1997). Sessile elements, especially hexactinellids, demosponges, bryozoans and gorgonians, prevail among the benthic fauna, constituting communities of suspension feeders with a three-dimensional structure which represent the most characteristic and richest in diversity and biomass of the Antarctic (Arntz, 1997). Such assemblages have been described from the east coast of the Weddell Sea (Voß, 1988; Galeron et al., 1992), the Ross Sea (Bullivant, 1967; Dayton et al., 1974; Gambi et al., 1994) and other zones of the high Antarctic (Ushakov, 1963).

However, suspension-feeder communities comparable to those of the Antarctic have not been found in the Magellan region (Arntz and Gorny, 1996). Although the Victor Hensen campaign frequently found ascidians, sponges, bryozoans and gorgonians in the channels of Tierra del Fuego, these groups were almost never dominant. Only the hydrozoans were much more common than in Antarctic waters, and some very large species of ascidians constituted $10 \%$ of the biomass at stations in the southern part of Beagle Channel (Arntz et al., 1996).

In the Scotia Arc region, the 'Antártida 8611' data highlighted the interesting differences and similarities in faunistic composition among areas. Regarding suspension-feeder groups, large hexactinellids and demosponges were more frequent and abundant on the shelves of South Georgia and Elephant Island (60\%) and, especially, at the South Orkney Islands (80\%); the ascidians contributed mainly off South Georgia, the South Orkneys and the South Sandwich Islands (Figs. 3-7); and, to a lesser degree, the calcareous bryozoans, pennatulids, dendrochirotid holothurians and crinoids, off the southernmost islands. Curiously, the frequency and abundance of colonial cnidarians, in particular hydrozoans, gorgonians, alcyonarians and madrepore scleractinian corals were much higher at Shag Rocks (Fig. 2), islands whose sedimentological singularity, compared with the rest, has already been noted (Acosta et al., 1989). Those taxa, responsible for the major dissimilarity average of the Shag Rocks with the others island, constituted a well defined group in the dendrogram obtained by the clustering analysis of occurrence and abundance of faunistic taxa (Fig. 10).

On the high Antarctic shelf, the zones dominated by suspension feeders are limited to depths unaffected by the pack ice and anchor ice (Bullivant, 1967; Dayton et al., 1970; Hamada et al., 1986; Gutt et al., 1999), and sometimes linked to the presence of a hard substratum (Voß, 1988). The question to what extent these communities are favoured or restricted by iceberg scouring is still under discussion (Gutt et al., 1998). In addition to these factors, high water-column productivity may play an important role in the massive presence of these suspension-feeder groups, particularly large long-lived 
sponges (Galéron et al., 1992; Bathmann et al., 1991), whereas a high level of inorganic sedimentation seems to act as an inhibitor (Kirkwood and Burton, 1988).

Although large sponge communities do not seem to reach the north-east of South Georgia Island or Shag Rocks, their presence in the northern Scotia Arc islands would show that, even at such "northerly' latitudes, there are some privileged areas that may reproduce environmental conditions of some habitats of the high Antarctic. The data collected during the 'Antártida 8611' campaign show that these large sponge communities are mainly located at 100-300 m depth, on hard bottoms and in areas with high primary productivity (Acosta et al., 1989; Mariño, 1989; Álvarez de Meneses, 1989). This would be the case of the Clerke Rocks shelf, east of South Georgia Island, north of Laurie and Coronation Islands, and south of Signy Island, in the South Orkneys (Ramos and Sobrino, 1991), and north-east of King George Island, in the South Shetlands. If the hypothesis of Clarke and Crame (1989) -that migration across the Scotia Arc island shelves has been very slow, and the present Southern Ocean shallowwater marine fauna largely evolved in situ - is true, these communities of large suspension-feeders would be relicts, and should have been existent in these areas since at least the Late Cretaceous.

Dense suspension-feeder communities are absent in the Magellan channels (Arntz et al., 1996), as well as in other extensive areas of the Scotia Arc archipelagos, such as the vast southern shelf of the South Orkneys (Ramos and Sobrino, 1991), west of Elephant Island, the shallow bays of the South Shetlands (Gallardo, 1992; Jazdzewski et al., 1986; SáizSalinas et al., 1997; Arnaud et al., 1998) and in Bransfield Strait (Mühlenhardt-Siegel, 1988, 1989; Ramil and Ramos, 1997). This could be due, among other factors, to their location, close to glacial fronts or in the frequent passage of large icebergs. In these zones, strongly disturbed due to high sedimentation and the consequent presence of muddy bottoms, sessile filter feeders would find it difficult to settle and feed, even under favourable organic input conditions (Kirkwood and Burton, 1988). Even though ascidians, sponges, bryozoans and gorgonians are found frequently in these areas, they seem to play a minor role, as has been suggested for the Magellan region (Arntz et al., 1996).

Unfortunately, the low number of stations off the South Sandwich Islands was insufficient to confirm whether large sponge communities extend to these islands or not. However, it is possible that, due to the youth of these islands -formed a mere 4 million years ago (Acosta et al., 1989)- and their active volcanism, these communities do not exist.

The massive presence of ascidians, especially of large molgulids, which seem to constitute an important part of the benthos on both sides of the Drake Passage and have also been reported from the Weddell Sea (Galéron et al., 1992; Gerdes et al., 1992), appears to be linked to unstable conditions as well. As they seem to grow faster than other invertebrates, particularly during some years (Kühne, 1997, cited by Arntz, 1997), they are probably more opportunistic, and could take over the ecological niche of other, much more demanding suspension feeders. This hypothesis could explain the ascidian dominance in zones with strong glacial influence, such as some bays of the South Shetlands, on bottoms less than 100 m depth (Jazdzewski et al., 1986; Kowalke, 1989; Sáiz-Salinas et al., 1997; Arnaud et al., 1998), or those subject to active volcanic conditions, such as the South Sandwich archipelago or inner and outer Deception Island (Retamal et al., 1982; SáizSalinas et al., 1997; Arnaud et al., 1998; Ramos, unpubl. data).

Regarding the occurrence of non-filter feeding taxa, as in other Antarctic and Subantarctic areas, the most widely distributed group along the Scotia Arc was the echinoderms, collected at $80-90 \%$ of stations, depending on the island groups. However, whereas ophiuroids and echinoids were frequent and abundant at both Shag Rocks and South Georgia, asteroids, holothurians and crinoids were dominant off the South Orkneys, Elephant Island and the South Shetlands (cf. Figs 2-7).

A striking point regarding the ophiuroids is that two species (Astrostoma agassizii and Asprospartum gigas) were responsible for their high abundances off Shag Rocks and South Georgia Island. As reported by Dearborn (1977) and Dearborn et al. (1986), A. agasizii preys on zooplankton, mainly on copepods and euphausiids, which are very abundant in South Georgian waters (Jansá, 1989). Considering this, almost the totality of the megabenthic epifauna on the South Georgia shelf would depend on the water column for its food supply. If this is the case, the proportion of fauna, both sessile and motile, that takes advantage of summer phyto- or zooplanktonic productivity would be similar to, or even higher than, that found at the highest latitude islands.

Taxa that were also found much more frequently off the islands close to the continent are, in addition 
to calcareous bryozoans, pennatulids and crinoids, cirripedes and errant polychaetes. This pattern is especially evident if the proportion of stations at which these taxa were also abundant or dominant is considered (cf. Figs. 2-7). Pycnogonids and large peracarid crustaceans (isopods and gammarids) also increased in frequency from Shag Rocks to Elephant Island and the South Shetlands. All these taxa, characteristic of the Antarctic benthos, have been clearly grouped in the dendrogram of the clustering analysis (cf. Fig. 10). Although they are also regularly found on the northern side of the Drake Passage, their sizes in general are much smaller, and they also seem to play a minor role in the Magellan region, where reptant decapods are more dominant. The abundance of stone crabs of the Lithodidae family in the Magellan channels is well known (Arntz et al., 1996). During the 'Antártida 8611' campaign they were found only off Shag Rocks and South Georgia Island (cf. Figs. 2 and 3), a geographical area considered the southernmost limit of their distribution in the South Atlantic (López Abellan and Balguerías, 1993), and they are linked to Cnidaria in the clustering dendrogram (cf. Fig. 10). Caridean shrimps are the only abundant decapod group on the Antarctic side (Ramos et al., 1987; Ramos and Sobrino, 1991; Arntz et al., 1996; Arntz, 1997).

The higher levels of occurrence and abundance of motile invertebrates - such as asteroids, holothurians, pycnogonids, large isopods and gammarids, caridean decapods and errant polychaetes - off the more southerly archipelagos of the Scotia Arc could be explained by the wide range of trophic adaptations of these groups in the face of a scarce food supply stemming from the persistence of sea ice at these latitudes. Indeed, many of these taxa are active predators, scavengers or with marked necrophagous tendencies (Arnaud, 1970, 1977; Presler, 1986), or have generalist feeding patterns (McClintock, 1994). The importance of the echinoderms as the subdominant group -particularly asteroids, ophiuroids and holothurians- from Elephant Island, the South Orkneys and the South Shetlands has also been noted by Mühlenhardt-Siegel (1988, 1989), Ramos and Sobrino (1991), Sáiz-Salinas et al. (1997), and Arnaud et al. (1998).

In short, it is impossible to know whether the large suspension-feeder assemblages existed to the west of South Georgia, at Shag Rocks and in the Magellan region prior to the definitive opening of the Drake Passage and if they subsequently disappeared due to changing oceanographic conditions.
However, the abundance of hydrozoans and anomuran decapods, as well as the minor proportion of crinoids, pycnogonids, large isopods and gammarids in the Magellan region as well as at Shag Rocks and South Georgia, could reflect that these regions were geographically much closer several tens of millions of years ago.

Some areas in the Scotia Arc archipelagos that seem to have relic communities -such as those comprising large sponges or bryozoans from South Georgia, the South Orkneys and east of King George, and the serpulid reef at South Georgiawhich currently lie outside the protection limits of the Antarctic Treaty, should be studied in more detail in order to propose them as Specially Protected Areas (Smith et al., 1994).

\section{ACKNOWLEDGEMENTS}

Thanks to my dear colleagues Carmen Piñeiro, Ignacio Sobrino and Luis Gil de Sola and to Eduardo Balguerías, our Campaign Chief, for his patience during the '8611'. To all my colleagues, and the Pesca Puerta Cuarto and Nuevo Alcocero crews, my thanks - particularly to Colon. Thanks to Patrick Arnaud, for his generous support; to CICYT, for financing the ANT95-1011 Project, enabling us to prepare the communications and papers presented at IBMANT 97; to Prof. Wolf Arntz and Dr. Ingo Wehrtmann, for their patience with me; and to Delories Dunn and Alvaro Peña for revising the English version of this paper. And thanks to Rocío González, my research fellow, whom I can always count on for support with graphs and computers.

\section{REFERENCES}

Acosta, J., M. Canals, P. Herranz and J.L. Sanz. - 1989. Investigación geológica-geofísica y sedimentológica en el arco de Escocia y península Antártica. In: MAPA (ed.), Resultados de la campaña "ANTÁRTIDA 8611", pp. 9-82. Publ. Espec. Inst. Esp. Oceanogr. $\mathrm{n}^{\circ}$ 2, Madrid.

Álvarez de Meneses, A. - 1989. Parámetros oceanográficos. In: MAPA (ed.): Resultados de la campaña "ANTÁRTIDA 8611, pp. 175-199. Publ. Espec. Inst. Esp. Oceanogr. no 2, Madrid.

Arnaud, P.M. - 1970. Frequency and ecological significance of necrophagy among the benthic species of Antarctic coastal waters. In: M. Holdgate (ed.), Antarctic Ecology, pp. 259-267. Academic Press, London, New York.

Arnaud, P.M. - 1977. Adaptations within the Antarctic marine benthic ecosystems. In: G. A. Llano (ed.), Adaptations within Antarctic Ecosystems, pp. 35-157. Proceed. $3^{\text {rd }}$ SCAR Symp. Antarct. Biol., Smithsonian Institution Washington DC, Gulf Publ. Co., Houston.

Arnaud, P.M. - 1992. The state of the art in Antarctic benthic research. In: V.A. Gallardo, O. Ferretti and H.I. Moyano (eds), Oceanografía en Antártica, pp. 341-345. ENEA-Proyecto 
Antártica-Italia. Centro Eula, Univ. Concepción, Ediciones Documentas, Santiago de Chile.

Arnaud, P.M., C.M. López, I. Olaso, F. Ramil, A.A. Ramos-Esplá and A. Ramos. - 1998. Semi-quantitative study of megabenthic fauna in the region of the South Shetland Islands and the Antartic Peninsula. Polar Biol., 19: 160-166.

Arntz, W.E. - 1997. Investigación antártica en biología marina: situación actual, proyectos internacionales y perspectivas. Bol. R. Soc. Esp. Hist. Nat. (Sec. Biol.), 93(1-4): 13-44.

Arntz, W.E., T. Brey and V.A. Gallardo. - 1994. Antarctic zoobenthos. Ocean. Mar. Biol. Ann. Rev., 32: 241-304.

Arntz, W.E. and M. Gorny. - 1996. Cruise report of the Joint Chilean-German-Italian Magellan "Victor Hensen" Campaign in 1994. Ber. Polarforsch., 190: 1-113.

Arntz, W.E., M. Gorny, M. Lardies, E. Mutschke and C. Ríos. 1996. Benthic macrofauna sampled with the Agassiz trawl. Ber. Polarforsch., 190: 43-51.

Balguerías, E. - 1989. Biología pesquera. In: MAPA (ed.), Resultados de la campaña "ANTARTIDA 8611, pp. 267-484. Publ. Espec. Inst. Esp. Oceanogr. $\mathrm{n}^{\circ}$ 2, Madrid.

Balguerías, E. - 1991. Informe de la campaña española de evaluación de los stocks de peces de Orcadas del Sur ("Antártida 9101"). CCAMLR, WG-FSA-91/33: 1-33.

Barnes, D.K.A. - 1995a. Sublittoral epifaunal communities at Signy Island, Antarctica. I. The ice-foot zone. Mar. Biol., 121: 555563.

Barnes, D.K.A. - 1995b. Sublittoral epifaunal communities at Signy Island, Antarctica. II. Below the ice-foot zone. Mar. Biol., 121: 565-572.

Bathmann, U., G. Fischer, P.J. Müller and D. Gerdes. - 1991. Shortterm variations in particulate matter sedimentation of Kapp Norvegia, Weddell Sea, Antarctica: relation of water mas advection, ice cover, plankton biomass and feeding activity Polar Biol., 11: 185-195.

Beliaev, G.M. - 1958. Some patterns in the quantitative distribution of bottom fauna in the Antarctic. Inf. Bull. Sov. Antarct. Exped., 1(3): 119-121.

Bullivant, J.S. - 1967. Ecology of the Ross Sea benthos. Bull. N. Z. Dep. Scient. Ind. Res., 176: 49-75.

Casas, C. - 1994. Octocorallia (Cnidaria, Anthozoa) del Arco de Scotia (Antártida), recogidos durante la campaña "Antártida 8611”. Memoria Tesis Licenciatura, Univ. Vigo.

Clarke, A. and J.A. Crame. - 1989. The origin of the Southern Ocean marine fauna. In: J. A. Crame (ed.), Origins and Evolution of Antarctic Biota, pp. 253-268. Geol. Soc. Spec. Publ., 47, London.

Clarke, K.R. and R.M. Warwick. - 1994. Change in Marine Communities: An Approach to Statistical Analysis and Interpretation. Natural Environment Research Council, UK.

Conde, F. and T. Gallardo. - 1991. Macrofitobentos de la Expedición "Antártida 8611". In: J. Castellví (ed.), Actas del IV Simposio Español de Estudios Antárticos, pp. 155-157. CICYT, Madrid.

Dalziel, I.W.D. - 1983. The evolution of the Scotia Arc: a review. In: R.L. Oliver, P.R. James and J.B. Jago (eds), Antarctic Earth Science, pp. 283-288. Cambridge University Press, Cambridge.

Dayton, P.K. - 1990. Polar benthos. In: W.O. Smith (ed.), Polar Oceanography. Part B: Chemistry, Biology and Geology, pp. 631-685. Academic Press, London.

Dayton, P.K., G.A. Robilliard and R.T. Paine. - 1970. Benthic faunal zonation as a result of anchor ice at McMurdo Sound, Antarctica. In: M. W. Holdgate (ed.), Antarctic Ecology, 1, pp. 244-258. Academic Press, London, New York.

Dayton, P.K., G.A. Robilliard, R.T. Paine and L.B. Dayton. - 1974. Biological accomodation in the benthic community at McMurdo Sound, Antarctica. Ecol. Monogr. 44: 105-128.

Dayton, P.K., B.J. Mordida and F. Bacon. - 1994. Polar marine communities. Am. Zool., 34: 90-99.

Dearborn, J.H. - 1977. Food and feeding characteristics of Antarctic asteroids and ophiuroids. In: G.A. Llano (ed.), Adaptations within Antarctic Ecosystems, pp. 293-326. Proceed. $3^{\text {rd }}$ SCAR Symp. Antarct. Biol., Smithsonian Institution Washington DC, Gulf Publishing Co, Houston.

Dearborn, J.H., F.D. Ferrari and K.C. Edwards. - 1986. Can pelagic aggregations cause benthic satiation? Feeding biology of the Antarctic brittle star Astrostoma agassizii (Echinodermata: Ophiuroidea). Biology of the Antarctic Seas XVII, Antarct. Res. Ser., 44: 1-28.
Dell, R.K. - 1972. Antarctic benthos. Adv. mar. Biol., 10: 1-216.

Elephteriou, A. and N.A. Holme. - 1984. Macrofauna techniques. In: N.A. Holme and A.D. McIntyre (eds), Methods for the Study of Marine Benthos, pp. 140-216. Blackwell Scientific Publications, Oxford.

Galéron, J.0., R.L. Herman, P.M. Arnaud, W.E. Arntz, S. Hain and M. Klages. - 1992. Macrofaunal communities on the continental shelf and slope of the southeastern Weddell Sea, Antarctica. Polar Biol., 12: 283-290.

Gallardo, V.A. - 1992. Estudios bentónicos en bahías someras antárticas de los Archipiélagos de las Islas Shetland del Sur. In: V.A. Gallardo, O. Ferretti and H.I. Moyano, (eds), Oceanografía en Antártica, pp. 383-393. ENEA - Proyecto Antártica - Italia. Centro Eula, Univ. Concepción, Ediciones Documentas, Santiago de Chile.

Gallardo, V.A. and J.C. Castillo. - 1969. Quantitative benthic survey of the infauna of Chile Bay (Greenwich Island, South Shetland Islands). Gayana, Zool., 16: 3-17.

Gallardo, V.A., J.G. Castillo, M.A. Retamal, A. Yáñez, H.I. Moyano and J.G. Hermosilla. - 1977. Quantitative studies on the soft-bottom megabenthic animal communities of shallow Antarctic bays. In: G.A. Llano (ed.), Adaptations within Antarctic Ecosystems, pp. 361-387. Proceed. $3^{\text {rd }}$ SCAR Symp. Antarct. Biol., Smithsonian Institution, Washington DC, Gulf Publishing Co, Houston.

Gambi, M.C., M. Lorenti, G.F. Russo and M.B. Scipione. - 1994. Benthic associations of the shallow hard bottoms off Terra Nova Bay, Ross Sea: zonation, biomass and population structure. Antarct. Sci., 6(4): 449-462.

García, F.J., J.C. García-Gómez, J.S. Troncoso and J.L. Cervera. 1994. A descriptive study of some Antarctic notaspidean opistobranchs (Gastropoda) with description of a new genus and species. Polar Biol., 14: 261-268.

Gerdes, D., M. Klages, W.E. Arntz, R.L. Herman, J. Galéron and S. Hain. - 1992. Quantitative investigations on megabenthos communities of the southeastern Weddell Sea shelf based on multibox corer samples. Polar Biol., 12: 291-301.

Gutt, J., A. Buschmann, J. Dijkstra, W. Dimmler, D. Piepenburg and N. Teixidó. - 1999. Study on benthic resilience of the macro- and megabenthos by imaging methods. In: W.E. Arntz and J. Gutt (eds), The Expedition ANTARKTIS XV/3 (EASIZ II) of RV 'Polarstern' in 1998, pp. 17-22. Ber. Polarforsch., 301, AWI, Bremerhaven.

Gutt, J., V. Storch and W.E. Arntz. - 1998. Benthosforschung im Südpolarmeer: Störung schafft Vielfalt. BIUZ, 28: 362-370.

Hamada, E., H. Numanami, Y. Naito and A. Taniguchi. - 1986. Observation of the marine benthic organisms at Syowa Station in Antarctica using a remotely operated vehicle. Mem. Natl. Inst. Polar Res., Spec. Issue, 40: 289-298.

Hardy, P. - 1972. Biomass estimates for some shallow-water infaunal communities at Signy Island, South Orkney Islands. Brit. Antarct. Surv. Bull., 30: 93-106.

Headland, R. - 1984. The Island of South Georgia. Cambridge University Press, Cambridge.

Jansá, J. - 1989. El zooplancton de los archipiélagos subantárticos. In: MAPA (ed.), Resultados de la campaña "ANTÁRTIDA 8611”, pp. 211-266. Publ. Espec. Inst. Esp. Oceanogr. no 2, Madrid.

Jazdzewski, K., W. Jurasz, W. Kittel, P. Presler and J. Sicinski. 1986. Abundance and biomass estimates of the benthic fauna in Admiralty Bay, King George Island. Polar Biol., 6: 5-16.

Kirkwood, J.M. and H.R. Burton. - 1988. Megabenthic species assemblages in Ellis Fjord, Westfold Hills, Antarctica. Mar. Biol., 97: 445-457.

Knox, G.A. and J.K. Lowry. - 1977. A comparison between the benthos of the Southern Ocean and the North Polar Ocean with special reference to the Amphipoda and the Polychaeta. In: M.J. Dunbar (ed.), Polar Oceans, pp. 423-462. Proceed. Polar Oceans Conference, Montreal, May 1974. Arctic Institute of North America.

Kowalke, J. - 1989. Energieumsätze benthischer Filtrierer der Potter Cove (King George Island, Antarktis). Ber. Polarforsch., 286: $1-147$.

Kühne, S. - 1997. Solitäre Ascidien in der Potter Cove (King George Island, Antarktis) - ihre ökologische Bedeutung und Populationsdynamik. Ber. Polarforsch., 252: 1-153.

López Abellan, L.J. and E. Balguerías. - 1993. On the presence of Paralomis spinosissima and Paralomis formosa in catches 
taken during the Spanish Survey ANTARTIDA 8611. CCAMLR Science, 1: 165-173.

López de la Cuadra, C.M. and J.C. García-Gómez. - 1997. Studies on recent Macroporidae (Bryozoa: Cheilostomatida), with new taxa and ontogeny of the ovicells. J. Zool. Lond., 242: 605-621.

Mariño, J. - 1989. Biomasa y composición del fitoplancton. In: MAPA (ed.), Resultados de la campaña "ANTÁRTIDA 8611", pp. 201-209. Publ. Espec. Inst. Esp. Oceanogr. n ${ }^{\circ}$ 2, Madrid.

McClintock, J. - 1994. Trophic biology of Antarctic shallow-water echinoderms. Mar. Ecol. Progr. Ser., 111: 191-202.

Mühlenhardt-Siegel, U. - 1988. Some results on quantitative investigations of megabenthos in the Scotia Arc (Antarctica). Polar Biol., 8: 241-248.

Mühlenhardt-Siegel, U. - 1989. Quantitative investigations of Antarctic zoobenthos communities in winter (May/June) 1986 with special reference to the sediment structure. Arch. Fisch Wiss., 39(1): 123-141.

Munilla, T. - 1991. Picnogónidos capturados en la campaña "Antártida 8611”. Bol. Inst. Esp. Oceanogr., 7(1): 3-44.

Peña-Cantero, A.L. and A.M. García-Carrascosa. - 1996. Hidrozoos bentónicos de la campaña "Antártida 8611". Publ. Espec. Inst. Esp. Oceanogr., 19. MAPA, Madrid.

Picken, G.B. - 1985. Marine habitats. - Benthos. In: W.N. Bonner and D.W.H. Walton (eds), Antarctica (Key Environments), pp. 154-172. Pergamon Press, Oxford.

Platt, H.M. - 1979. Ecology of King Edward Cove, South Georgia: macro-benthos and the benthic environment. Brit. Antarct. Surv. Bull., 49: 231-238.

Presler, P. - 1986. Necrophagous invertebrates of the Admiralty Bay of King George Island (South Shetland Islands, Antarctica). Polar Res., 7(1-2): 25-61.

Ramil, F. and A. Ramos. - 1997. Estudio de la fauna bentónica asociada a los edificios volcánicos de la cuenca central del Estrecho de Bransfield. In: J.R. Vericad and J. Cacho (eds): Informe sobre las Actividades Científicas de España en la Antártida durante la Campaña 1996-97, pp. 21-30. CICYT, Madrid.

Ramos, A. - 1987. Invertebrados. In: Informe de Resultados "Antartida 8611". Inf. Int. Inst. Esp. Oceanog. (mimeo).

Ramos, A., I. Sobrino, L. Gil de Sola and C. Piñeiro. - 1987. Un examen general del macrobentos de los archipiélagos del Arco de Escocia, encontrados durante la Campaña "Antártida 8611". In: J. Castellví (ed.), Actas del Segundo Simposio Español de Estudios Antárticos, pp. 353-364. C.S.I.C., Madrid.

Ramos, A. and I. Sobrino. - 1991. Análisis preliminar del macrobentos capturado en la Campaña "Antártida 9101". In: J. Castellví. (ed.), Actas del Cuarto Simposio Español de Estudios Antárticos., pp. 141-153. CICYT, Madrid.

Ramos, A. and G. San Martin. - 1999. On the finding of a mass occurrence of Serpula narconensis Baird, 1885 (Polychaeta, Serpulidae) in South Georgia (Antarctica). Polar Biol. (in press).

Retamal, M.A., R. Quintana and F. Neira. - 1982. Análisis cuali y cuantitativo de las comunidades bentónicas en Bahía Foster (Isla Decepción) (XXXV Expedición Antártica Chilena, enero 1981). Publ. Inst. Antárt. Chil. Ser. Cient., 29: 5-15.

Sáiz-Salinas, J.I., A. Ramos, F. J. García, J.S. Troncoso, G. San Martin, C. Sanz and C. Palacín. - 1997. Quantitative analysis of megabenthic soft-bottom assemblages in the South Shetland waters (Antarctica). Polar Biol., 17: 393-400.

Smith, R.I.L., D.W.H. Walton and P.R. Dingwall. - 1994. Developing the Antarctic Protected Area System. Proceedings of the SCAR/IUCN Workshop on Antarctic Areas, Cambridge, UK, 29 June - 2 July 1992, Conservation of Southern Polar Regions, 1.

Ushakov, P.V. - 1963. Quelques particularités de la bionomie benthique de l'Antarctique de l'Est. Cah. Biol. Mar., 4: 81-89.

Voß, J. - 1988. Zoogeography and community analysis of megabenthos of the Weddell Sea (Antarctica). Ber. Polarforsch., 45: 1-145. 